\title{
Selection of Microorganisms Degrading S-Metolachlor Herbicide
}

\author{
Paula Fabiane Martins ${ }^{1}$, Camila Ortiz Martinez ${ }^{1}$, Giselle de Carvalho ${ }^{1}$, Paulo Irajara \\ Borba Carneiro $^{2}$, Ricardo Antunes Azevedo ${ }^{3}$, Sônia Alvim Veiga Pileggi ${ }^{1}$, Itamar Soares de \\ Melo $^{3}$ and Marcos Pileggi ${ }^{*}$ \\ ${ }^{I}$ Departamento de Biologia Estrutural, Molecular e Genética; Universidade Estadual de Ponta Grossa; Ponta \\ Grossa - PR - Brasil. ${ }^{2}$ Departamento de Química Geral; Universidade Estadual de Ponta Grossa; Ponta Grossa - \\ PR - Brasil. ${ }^{3}$ Departamento de Genética; Escola Superior de Agricultura Luiz de Queiroz; Universidade de São \\ Paulo; São Paulo - SP - Brasil. ${ }^{3}$ Embrapa Meio Ambiente; Jaguariúna - SP - Brasil
}

\begin{abstract}
The aim of this work was to study herbicide degradation through selected microorganisms from humus and soil subjected to different plantation systems. The following bacterial species were identified: Klebsiella pneumoniae pneumoniae GC s.B strain 1, Pseudomonas alcaligenes, Enterobacter aerogenes GC s.A and Klebsiella pneumoniae pneumoniae GC s.B strain 2. Growth studies yet suggested the possibility of a very long lag phase. Although, culture with the herbicide presented biofilm formation and there were color changes in the herbicide that could have interfered with the espectrophotometry readings. After 5 days of incubation at $35^{\circ} C$, the difference in the concentration of herbicide was $14.42 \%$ on average and after 10 days, $35.01 \%$.
\end{abstract}

Key words: Bioremediation, biodegradation, S-Metolachlor, herbicide

\section{INTRODUCTION}

With the modernization of agriculture in the 60 's, a massive use of agrochemicals, fertilizers and machinery began, aimed at improving field productivity. These goals have been achieved, although the side effects of this situation include an intense and abusive utilization of these chemicals, creating many kinds of problems (Fay et al., 1997). The agrochemical impact on the environment is clear, but measuring its effects is difficult. Residues can cause damage and bring about disease to plants in a rotation culture system in a cumulative manner, restricting microbial growth (Frighetto, 1997; Rickman et al., 2002). For these reasons, human health and the sustainability of animal life in adjacent environments might be affected (Blanco, 1979; Freemark and Boutin, 1995). Due the persistence of some compounds, the percolation of permeable soils could be a source of underwater pollution, principally in aquifers (Barbash et al., 2001). Nevertheless, one of the more promising fields of biotechnology matter is the bioremediation (Bouwer et al., 1994; Potrawfke et al., 1998). Herbicides respond for $65 \%$ of all agrochemical demands in the world and in particular in Brazil. (Fay et al., 1997). Some studies have shown that more than half of states of the USA have contaminated groundwater (Battaglin et al., 2000). S-Metolachlor herbicide [2-chloro-N-(2-ethyl-6methylphenyl)-N-(2-metoxi-1-methylethyl)

${ }^{*}$ Author for correspondence 
acetamide] is one of the three most used herbicides in the world in the chloroacetanilide class. This herbicide has a high toxicity and can be leached, representing a powerful source of groundwater pollution (Liu et al., 2001; Scribner et al., 2000; Ferrer et al., 1997; Rodrigues and Almeida, 1998). Generally, acetanilide residues and their metabolites are common in aquifers in close proximity to agricultural soils where these herbicides have been applied (Stamper and Tuovinen, 1998). Acetanilide biodegradation is a very important factor for its elimination in aerobic and anaerobic environments. Hydrolysis is not as important in soil and water $\mathrm{pH}$ conditions, while adsorption in argil and organic matter probably retards the biodisposability (Stamper and Tuovinen, 1998). These herbicides are somewhat resistant to photodecomposition (Humburg et al., 1989). In several organisms, the greatest factor of acetanilide transformation is detoxification by glutation-S-transferase (GST) (Stamper and Tuovinen, 1998; Zablotowicz et al., 1995; Hammond et al., 1983). Despite this, microorganisms do not easily metabolize aromatic fragment (Liu et al., 1987), raising a serious environmental concern.

Until now, pure bacterial cultures able to metabolize acetanilide or its sulfonate derivatives have not been described in the literature. Tiedje and Hagedorn (1975) were able to isolate a soil fungus, Chaetomium globosum, which could partially transform alachlor into several metabolites, but the aromatic ring remained intact. About 6 to $14 \%$ of the alachlor herbicide was metabolized by Ceriporiopsis suvermispora, Phelebia tremellosa e Phanerochaete chrysosporium, after 122 days of incubation (Ferrey et al., 1994). The low degree of enzymatic degrading of this herbicide suggests that a cometabolism hypothesis might be possible. Chaetomium globosum fungus is able to utilize $55 \%$ of the Metolachlor molecules as a unique carbon source, in a 6 day period, without altering the aromatic ring, with a high level of byproduct production (Saxena et al. 1987; Liu et al., 1989). Other bacteria and fungi capable of metabolizing Metolachlor were isolated (Saxena et al., 1987; Liu et al., 1989), but the break down of the ring has not been successfully obtained as yet. Propachlor was the only herbicide of this group passive enough to be completely metabolized (Villarreal et al., 1991).
Questions such as the lack of information about SMetolachor degradation, the possibility of environmental contamination by this herbicide, the fact that its degradation would be essentially performed by microorganisms, constituted the basis of this work. The following experimental tasks were performed on soil microorganisms from herbicide free humus and direct and conventional plantings soils subjected to S-Metolachor treatment: isolation in selective culture media, capsule coloration, halo determination in solid media culture, biochemical identification and the monitoring of herbicide concentration using ultraviolet spectrophotometry.

\section{MATERIALS AND E METHODS}

\section{Sampling}

The soil samples used to isolate the microorganisms were humus (from Ascomycota) without the herbicide and direct and conventional plantings soils treated with S-Metolachor herbicide. The source of the herbicide was a trade brand called Dual Gold at a concentration of 960 g.L $\mathrm{L}^{-1}$. Commercial humus and agricultural sandy-argil soils were obtained in Ponta Grossa city, Parana State, Brazil. The pH of these soils was determined.

\section{Tolerant microorganism selection}

Serial dilution in $\mathrm{NaCl} 0,85 \%$ was performed at concentrations of $10^{-2}, 10^{-3}, 10^{-4}$ and $10^{-5}$. These samples were inoculated in Nutrient ( $\mathrm{pH} 7.0)$ and Sabouraud ( $\mathrm{pH}$ 5.6) Agars, which was applied in the presence and absence of the herbicide in duplicate, and incubated at $35^{\circ} \mathrm{C}$ and $25^{\circ} \mathrm{C}$. Herbicide concentration was used according to Melo and Azevedo (1997). The culture media were sterilized by autoclavation. Statistical counting and the isolation of pure cultures were performed in agar media cultures presenting 25 to 300 colonies forming units (cfu).

\section{Herbicide concentration evaluation}

Ultraviolet spectroscopy at $210 \mathrm{~nm}$ was used to perform S-Metolachor herbicide calibration curves and to monitory its sample concentration (Fig. 1). This calibration curve shows a correlation between herbicide concentration $(\mathrm{g} / \mathrm{mL})$ and absorbance at $210 \mathrm{~nm}$. 


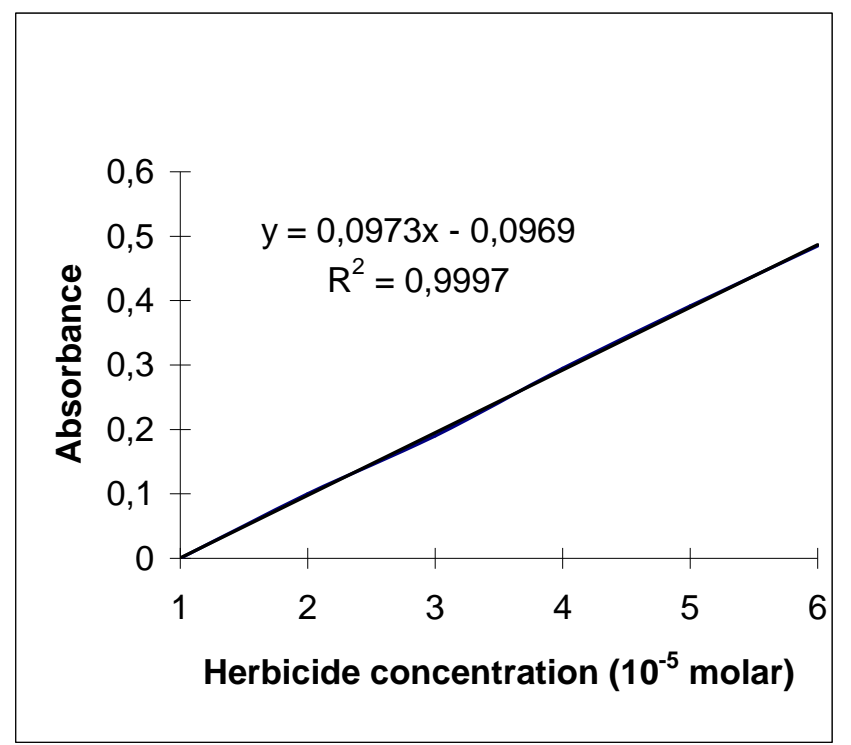

Figure 1 - Calibration curve of S-Metolachlor, herbicide. Initial concentration of herbicide was $1.53610^{-4} \mathrm{~g} / \mathrm{mL}$.

An initial herbicide concentration of $1.53610^{-4}$ $\mathrm{g} / \mathrm{mL}$ was added to the culture medium. Duplicate inocula were incubated at $35^{\circ} \mathrm{C}$ in $10 \mathrm{~mL}$ of Nutrient and Sabourad broth for 5, 10, 15, and 30 days. The absorbency was measured after the different incubation periods.

\section{Bacterial identification}

Morphological features by Gram staining and biochemical probes (gas production, $\mathrm{H}_{2} \mathrm{~S}$ production, urea hydrolysis; tryptophan deamination; motility, lysine and ornithine decarboxylation, indole production, citrate assimilation, lactose and arabinose fermentation Probac do Brasil Produtos Bacteriológicos Ltda.) were performed to first step identification of herbicide tolerant bacteria. Each strain was further identified by analysis of fatty acid methyl-esters (FAMEs) using the Microbial Identification System developed by Microbial ID (MIDI, Newark, DE). Cellular fatty acids were extracted according to the method of Sasser (1990). Fatty acid methyl-esters from each strain were separated using a Hewllett-Packard gas chromatograph model fitted with a fused silica capillary column (25 m x $0.2 \mathrm{~mm}$ internal diameter). FAME peaks were named by the MIS software, and bacterial strains were identified using the MIS "Aerobia Library" (Version TSBA50).

\section{RESULTS AND DISCUSSION}

The humus and agricultural soil samples $\mathrm{pH}$ were 5.8 and 5.5 respectively. Hence, Sabouraud Broth and Nutrient Broth were used because of their similarity to the soil $\mathrm{pH}$ with the result that the microbes demonstrated better growth on the media. The growth data from isolated microorganisms showed that S-Metolachlor presented a high selectivity. In the presence of this herbicide, just $3 \mathrm{cfu}$ on average isolated from the humus were found in the Nutrient Agar and $3 \mathrm{cfu}$ on average in the Sabouraud Agar, at a dilution of $10^{-3}$. Data from the agricultural soil showed an average number of $10 \mathrm{cfu}$ in the Nutrient Agar and $6 \mathrm{cfu}$ in the Sabouraud Agar. No microbial growth was observed at a dilution of $10^{-4}$. In the absence of S-Metolachlor, bacterial growth exceeded 300 cfu for all soils. The data from bacterial type soil origin, identification and herbicide degradation percentages are found in Table 1.

In spite of the fact that the humus was not a selective soil, due the absence of the herbicide, one bacterium capable of achieving the degradation, Klebsiella pneumoniae pneumoniae GC s.B strain 1, showing a high degradation rate in five days was obtained. Three bacterial strains metabolized S-Metolachlor from the agricultural soil. 
Table 1 - Degradation data of bacteria strains isolated from humus and agricultural soils, after 5, 10, 15 and 30 days of evaluation. The numeric values are the herbicide concentration left after microorganism degradation $(\mathrm{g} / \mathrm{mL})$. The numbers in parenthesis represent the degradation percentage $\left(\%\right.$ of $1.53610^{-4} \mathrm{~g} / \mathrm{mL}$ - herbicide degradation left after microorganism degradation).

\begin{tabular}{|c|c|c|c|c|c|}
\hline & & \multicolumn{4}{|c|}{ Degradation values } \\
\hline Soil Type & Bacteria & 5 days & 10 days & 15 days & 30 days \\
\hline Humus & $\begin{array}{c}\text { Klebsiella pneumoniae } \\
\text { pneumoniae GC s.B strain } 1\end{array}$ & $\begin{array}{c}1.181 \times 10^{-4} \\
(23.1)\end{array}$ & $\begin{array}{l}1.132 \times 10^{-4} \\
(26.3)\end{array}$ & $\begin{array}{l}9.231 \times 10^{-5} \\
(39.9)\end{array}$ & $\begin{array}{c}\text { Not } \\
\text { available }\end{array}$ \\
\hline $\begin{array}{c}\text { Direct plantation } \\
\text { system }\end{array}$ & Pseudomonas alcal & $\begin{array}{c}1.247 \times 10^{-4} \\
(18.8)\end{array}$ & $\begin{array}{l}1.084 \times 10^{-4} \\
(29.4)\end{array}$ & $\begin{array}{l}1.084 \times 10^{-4} \\
(29.4)\end{array}$ & $\begin{array}{c}8.602 \times 10^{-5} \\
(44.0)\end{array}$ \\
\hline $\begin{array}{c}\text { Conventional } \\
\text { plantation }\end{array}$ & $\begin{array}{c}\text { Enterobacter aerogenes } G C \\
\text { S.A }\end{array}$ & $\begin{array}{c}1.536 \times 10^{-4} \\
(0.0)\end{array}$ & $\begin{array}{l}1.382 \times 10^{-4} \\
(10.0)\end{array}$ & $\begin{array}{l}1.298 \times 10^{-4} \\
(15.5)\end{array}$ & $\begin{array}{c}8.325 \times 10^{-5} \\
(45.8)\end{array}$ \\
\hline System & $\begin{array}{c}\text { Klebsiella pneumoniae } \\
\text { pneumoniae } G C \text { s.B strain } 2\end{array}$ & $\begin{array}{c}1.269 \times 10^{-4} \\
(17.4)\end{array}$ & $\begin{array}{l}5.990 \times 10^{-5} \\
(61.0)\end{array}$ & Not available & $\begin{array}{l}1.536 \times 10^{-6} \\
(99.0)\end{array}$ \\
\hline
\end{tabular}

One of them, another strain of Klebsiella pneumoniae pneumoniae GC s.B strain 2, isolated from conventional plantation soil, was able to metabolize $99 \%$ of the herbicide.

Based on readings after a 30-day period, growth curve could be obtained because of an herbicide coloration change in the growth culture, which prejudiced the corresponding absorbency reading. This reinforced the degradation hypothesis, as the active compound of the herbicide was colored, and after degradation, became colorless. Additional experiments with colony counting in Nutrient Agar and Nutrient Agar-Metolachlor with Pseudomonas alcaligenes (data not shown) demonstrated a faster bacterial growth rate in a selective medium than in a rich medium culture. In plate agar medium, halo formation was observed around the bacterial colony, indicating herbicide degradation as cited by Alley and Brown, 2000 (Fig. 2).

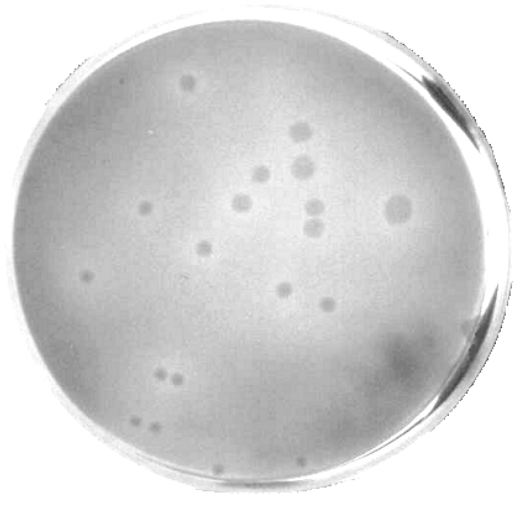

Figure 2 - Enterobacter aerogenes GC s.A colonies surrounded by degradation halos in Nutrient Agar medium with S-Metolachlor.

Some qualitative aspects relative to Klebsiella pneumoniae pneumoniae GC s.B strain 2 was observed. The medium viscosity was enhanced during bacterial growth in the presence of the herbicide, probably due to biofilm formation, which could improve the degradation by an aggregated microorganism pool (Araujo et al., 2004) (Figs. 3 and 4). The material obtained from biofilm in flask from Fig. 3 was used to prepare the slide (Fig. 4). Beside the color change during degradation, in the broth culture with the herbicide a decrease in decantation was observed, when compared to the control without the bacteria. The explanation for this phenomenon could be that herbicide degradation generates small particles that were more soluble than the non-degraded and larger particles of the herbicide in the medium suspension. This was also observed for all the 
other bacterial strains. These data reinforced the hypothesis of S-Metolachlor microbiological degradation.

S-Metolachlor (three-dimensional structure represented in Fig. 5) was a very selective herbicide, as only four bacteria were isolated from the soil samples (humus, direct system and conventional system plantation soils). The S-
Metolachlor degradation rate yield was far superior to that shown by alachlor, another acetanilide compound, according to Ferrey et al. (1994), who observed around 6 to $14 \%$ of degradation by Ceriporiopsis suvermispora, Phelebia tremellosa and Phanerochaete chrysosporium, after 122 days of incubation.

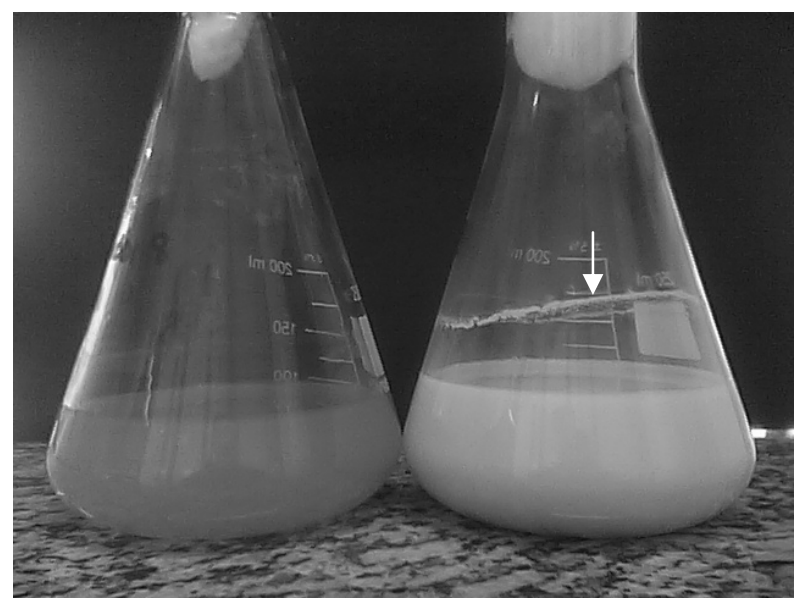

Figure 3 - Biofilm formation (arrow) in culture flask from Klebsiella pneumoniae pneumoniae GC s.B strain 2 only in Sabouraud-S-Metolachlor broth. There is no biofilm in left flask from Klebsiella pneumoniae pneumoniae GC s.B strain 2 in Sabouraud broth.

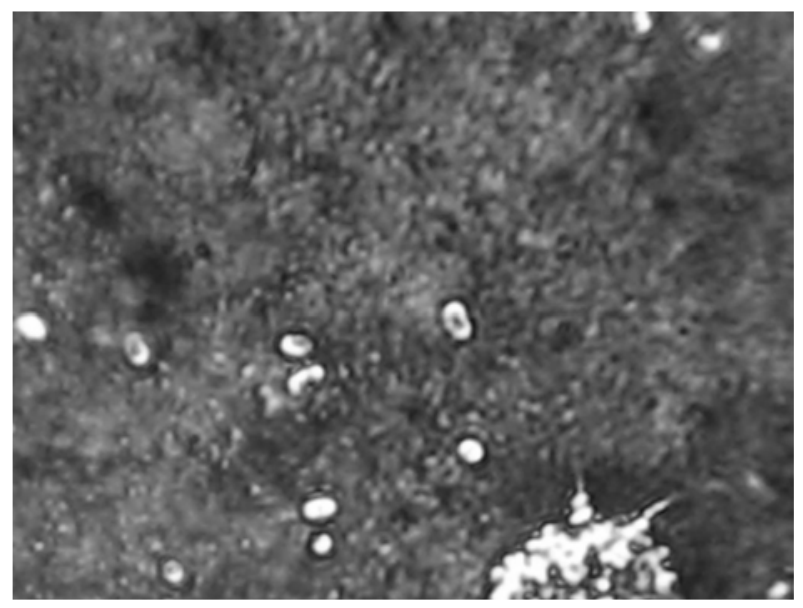

Figure 4 - Capsule coloration with Klebsiella pneumoniae pneumoniae GC s.B strain 2, from biofilm samples of Sabouraud- S-Metolachlor culture flasks.

Studies on bacterial growth in the presence of the herbicide, genetic expression regulation and proteomic and structural three-dimensional resolution (Fig. 5, shows the chlorine atom pointed by an arrow, which was highly relevant to the toxicity of the herbicide) would be necessary to accomplish a better understanding of microbial herbicide degradation under the influence of abiotic conditions. The metabolic knowledge and their enzymes would be of crucial importance in 
biotechnological products discovery, in which one microorganism could harbor different genes codifying several pathways related to herbicide degradation.

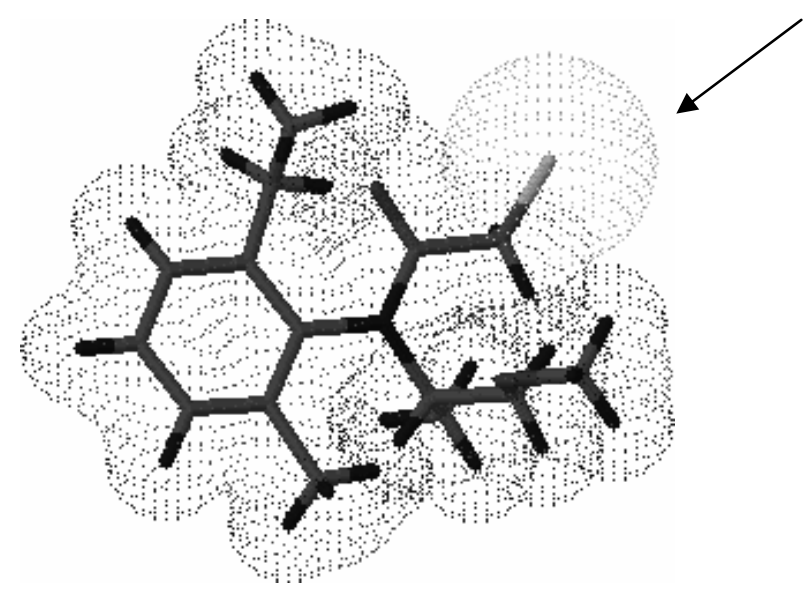

Figure 5 - The three-dimensional structure of the s-Metolachlor herbicide

The results obtained showed the number of possible bacterial strains capable of S-Metolachlor degradation was four. This hypothesis was supported by bacterial growth, colony halo formation in the Nutrient Agar plate media, color changes through degradation, viscosity changes and spectrophotometer data. These strains have to be further evaluated for genomic and proteomic approaches, in order to obtain a biotechnological product for use in bioremediation processing.

\section{AKNOWLEDGEMNTS}

The authors would like to thank Prof. Dr. Akemi Teramoto de Camargo for spectrophotometry assistance, and Jefferson Zagonel and Eloir Moresco, from the School-Farm "Capão da Onça", State University of Ponta Grossa for herbicides technical pieces of information.

\section{RESUMO}

Os herbicidas representam $65 \%$ do consumo geral, sendo que o S-Metolachlor é um dos mais utilizados e está trazendo preocupações ambientais. Objetivamos detectar a degradação do S-Metolachlor por microorganismos de solos sob plantio. Foram identificadas as espécies bacterianas: Klebsiella pneumoniae pneumoniae GC s.B linhagem 1, Pseudomonas alcaligenes,
Enterobacter aerogenes GC s.A e Klebsiella pneumoniae pneumoniae GC s.B linhagem 2. Resultados da curva de crescimento por espectrofotometria não permitiram definir diferentes fases, levando a pensar em uma fase Lag longa. Frascos de cultura demonstraram a formação de biofilme, provocando mudança na cor do herbicida, interferindo na leitura do crescimento. É possível a existência de fase Log, mas não detectável pelo método. Após 5 dias de incubação a $35^{\circ} \mathrm{C}$, a diferença média de concentração do S-Metolachlor foi de $14.42 \%$, e em 10 dias, $35.01 \%$. Observou-se o aparecimento de um halo em volta das colônias, o que corrobora a hipótese de degradação microbiana do herbicida.

\section{REFERENCES}

Alley, J. F., Brown, L. R. (2000) Use of sublimation to prepare solid microbial media with water-insoluble substrates. Appl. Environ. Microbiol., 66(1):439-442.

Araujo, J.C., Mortara, R., Campos, J.R., Vazoller, R.F. (2004) Development and analysis of anaerobic biofilms onto hydrophobic and hydrophilic surfaces. Environ. Technol., 25(7),809-17.

Barbash, J.E., Thelin, G.P., Kolpin, D.W., Gilliom, R.J. (2001) Major herbicides in ground water: results from the National Water-Quality Assessment. J. Environ. Qual., 30(3),831-45. 
Battaglin, W. A.; Furlong, E. T.; Burkhardt M. R.; Peter C. J. (2000) Occurrence of sulfonylurea, sulfonamide, imidazolinone, and other herbicides in rivers, reservoirs and ground water in the Midwestern United States, 1998. Sci. Total Environ., 248(2-3), 123-33.

Blanco, H. G. (1979) Destino, comportamento e resíduos dos herbicidas no solo. O Biológico, 45, 225-248.

Bouwer, E.; Durant, N.; Wilson, L.; Zhang, W.; Cunningham, A. (1994) Degradation of xenobiotic compounds in situ: capabilities and limits. FEMS Microbiology Rev., 15(2/3), 307-17.

Fay, E. F., Souza Silva, C. M. G., Melo, I. S. (1997) Degradação abiótica de xenobióticos. In: Microbiologia Ambiental, Ed. by Melo I. S. and Azevedo J. L., EMBRAPA-CNPMA, Jaguariúna, pp. 125.

Ferrer, I.; Thurman, E. M.; Barcelo, D. (1997) Identification of ionic chloroacetanilide-herbicide metabolites in surface water and groundwater by HPLC/MS using negative ion spray. Anal. Chemistry, 69(22), 4547-53.

Ferrey, M. L., Koskinen, W. C., Blanchette, R. A., Burnes, T. A. (1994) Mineralization of alachlor by lignin-degrading fungi. Can J Microbiol., 40 : (9), 795-798.

Freemark, K. and Boutin, C. (1995) Impacts of agricultural herbicide use on terrestrial wildlife in temperature landscapes: a review with special reference to North America. Agriculture, Ecosystems and Environment, (52), 67-91.

Frighetto, R. T. S. (1997) Impacto ambiental decorrente do uso de pesticides agrícolas. In: Microbiologia Ambiental, Ed. by Melo I. S. and Azevedo J. L., EMBRAPA-CNPMA, Jaguariúna, pp. 415.

Hammond, P. M., Price, C. P., Scawen, M. D. (1983) Purification and properties of aryl acylamidase from Pseudomonas fluorescens ATCC 39004. Eur. J. Biochem. 132(3):651-655.

Humburg, N. E., Colby, S. R., Hill, E. R., Kichen, L. M., Lin, R.G., McAvoy, W. J., Prasad, R. (1989) Herbicide Handbook of the Weed Science Society of America. Weed Science Society of America, 6th ed. Champaign. pp. 301.

Liu, S. R., Minard, R. D., Bollag, J. M. (1987) Soilcatalyzed complexation of the pollutant 2,6diethylaniline with syringic acid. J. Environ. Quality, 16: 48-53.

Liu, S. Y., Zheng, Z., Zhang, R., Bollag, J. M. (1989) Sorption and Metabolism of Metolachlor by a Bacterial Community. Appl. Environ. Microbiol., 55(3):733-740.

Liu, W.P., Liu, H.J., Zheng, W., Lu, J.H. (2001) Adsorption of chloroacetanilide herbicides on soil (I). Structural influence of chloroacetanilide herbicide for their adsorption on soils its components. J. Environ. Sci., 13(1), 37-45.
Melo, I. S., Azevedo, J. L. Como isolar microrganismos degradadores de moléculas xenobióticas. In: Microbiologia Ambiental, Ed. by Melo I. S. and Azevedo J. L., EMBRAPA-CNPMA, Jaguariúna, pp.167.

Potrawfke T., Timmis K. N., Wittich R. (1998) Degradation of 1,2,3,4-tetrachlorobenzene by Pseudomonas chlororaphis RW71. Applied and Environmental Microbiology, 64(10), 3798-3806.

Rickman, R.; Douglas, C.; Albrecht, S.; Berc, J. (2002) Tillage, crop rotation, and organic amendment effect on changes in soil organic matter. Environ Pollut.,116(3), 405-11.

Rodrigues B. N., Almeida F. D. (1998) Guia de Herbicidas, 4th ed., Londrina. 647 pp.

Sasser, M. (1990) Identification of bacteria through fatty acid analysis. In: Methods in Phytobacteriology. Ed. by Z, Klement, K. Rudolph and D. Sands. Akademiai Kiato, Budapest. pp. 199-204.

Saxena, A., Zhang, R.W., Bollag, J. M. (1987) Microorganisms capable of metabolizing the herbicide metolachlor. Appl. Environ. Microbiol., 53(2):390-396.

Scribner E. A., Battaglin W. A., Goolsby D. A., Thurman E. M. (2000) Changes in herbicide concentrations in Midwestern streams in relation to changes in use, 1989-1998. Sci. Total Environ., 248(2-3):255-263.

Stamper D.M., Tuovinen O.H. (1998) Biodegradation of the acetanilide herbicides alachlor, metolachlor, and propachlor. Crit. Rev. Microbiol.;24(1):1-22.

Villarreal, D.T., Turco, R.F., Konopka, A. (1991) Propachlor Degration by a Soil Bacterial Community. Appl. Environ. Microbiol., 57: 2135-2140.

Tiedje, J. M., Hagedorn, M.J. (1975) Degradation of alachlor by a soil fungus, Chaetomium globosum. $J$. Agric. Food Chem., 23(1):77-81.

Zablotowicz, R. M., Hoagland, R. E., Locke, M. A., Hickey, W. J. (1995) Glutatione-S-transferase Activity and Metabolism of Glutatione Conjugates by Rhyzosphere Bacteria. Appl. Environ. Microbiol., 61: 1054-1060.

Received: March 23, 2005; Revised: September 03, 2005; Accepted: October 11, 2006. 


\section{FOLHA}

EM

BRANCO 